\title{
Antibacterial Activity of Lactic Acid Bacteria and Extraction of Bacteriocin Protein
}

\author{
Rabiul Islam1, Md. Nur Hossain², Md. Khasrul Alam³, Md. Ekhlas Uddin4, Mehadi Hasan Rony3, \\ Md. Abu Sayeed Imran³, Md. Firoz Alam³
}

${ }^{1}$ Divisional DNA Screening Laboratory, Faridpur Medical College Hospital, Ministry of Women \& Children Affairs, Faridpur, Bangladesh

${ }^{2}$ Industrial Microbiology Laboratory, Institute of Food Science \& Technology, Bangladesh Council of Scientific \& Industrial research, Dhaka, Bangladesh

${ }^{3}$ Department of Biotechnology \& Genetic Engineering, Islamic University, Kushtia, Bangladesh ${ }^{4}$ Department of Biochemistry and Molecular Biology, Gono Bishwabidyalay, Dhaka, Bangladesh Email: rabiulbtge@gmail.com

How to cite this paper: Islam, R., Hossain, Md.N., Alam, Md.K., Uddin, Md.E., Rony, M.H., Imran, Md.A.S. and Alam, Md.F. (2020) Antibacterial Activity of Lactic Acid Bacteria and Extraction of Bacteriocin Protein. Advances in Bioscience and Biotechnology, 11, 49-59.

https://doi.org/10.4236/abb.2020.112004

Received: January 15, 2020

Accepted: February 23, 2020

Published: February 26, 2020

Copyright (c) 2020 by author(s) and Scientific Research Publishing Inc. This work is licensed under the Creative Commons Attribution International License (CC BY 4.0).

http://creativecommons.org/licenses/by/4.0/

\begin{abstract}
Biopreservation systems in foods are of increasing interest for industry and consumers. Bacteriocin producing Lactobacillus spp. is considered Generally Recognize as Safe (GRAS), useful to control the fast development of pathogens and spoiling microbes in food and feed. Lactobacillus spp. was isolated from traditional winter fermented vegetable cucumber \& carrot by the use of selective media. Especially De Man, Rogosa and Sharpe (MRS) Agar media were used to isolate the Lactobacillus species. Morphologically identified by gram staining \& colony morphology. Biochemically recognized by catalase, oxidase, MRVP \& carbohydrate fermentation test. Antimicrobial activity of Lactobacillus spp. was confirmed by Well Diffusion Method. Molecular characterization of bacteriocin protein and molecular weight determined by SDS PAGE method. The isolate was found to be facultative anaerobic, Gram positive, and catalase negative. The result of antimicrobial activity measured by the Arbitrary Unit $(\mathrm{AU} / \mathrm{ml})$ of zone of the inhibition. Six isolates found from the sample but most activities exhibited isolate 4 against Bacillus megaterium $(55 \mathrm{~mm})$ zone of diameter. The molecular weight of the washed bacteriocin was calculated to be about $40 \mathrm{kDa}$ (Isolate 1) and $15 \mathrm{kDa} \& 30 \mathrm{kDa}$ (Isolate 5). Bacteriocin protein reduces chemical preservatives and uses in future as biopreservative in food industry.
\end{abstract}

\section{Keywords}

Lactobacillus spp., Bacteriocin, Antimicrobial Activity, SDS PAGE, Biopreservative 


\section{Introduction}

Control of both pathogenic and spoilage microbe in a variety of foods is important to guarantee food quality and safety. Recently, biopreservation has arrived a topic of interest [1]. This technique is used as an alternative to chemical additives for rising self-life storage and augment safety of food by using native microflora and their antimicrobial products [2]. Lactic acid bacteria are trusted to be safe because they have been long effective as the normal flora in fermented food; thus, they have great potential for use in biopreservation. The conserving effects of lactic acid bacteria are due to the production of antimicrobial agents such as organic acids, hydrogen peroxide and bacteriocin or related substances [3] [4].

Modern food processing is currently facing a challenge in that it aims to extend shelf-life and safety of foods and beverages by chemical means, while on the other hand consumers prefer foods that are minimally processed and free from chemical preservatives. This has aroused great interest in so-called "green technologies" including new strategies to minimally process and exploit microbial metabolites for biopreservation [5] [6] [7]. Lactic acid bacteria (LAB) are generally recognized as safe and play a significant role in food and feed fermentation and preservation either as the native microflora or as starter cultures added under controlled conditions. The preservative effect exerted by LAB is mainly due to the production of organic acids (such as lactic acid) which result in lowered $\mathrm{pH}$ [8].

Lactic acid bacteria (LAB) have been extensively studied for their commercial potential [9], food preservation and health benefits. They are industrially significant microorganisms used worldwide primely in the dairy industry for manufacturing fermented milk products and cheese. Industrial importance of LAB is based on their capability to ferment sugars readily into different metabolites and provide an efficient method for preserving fermented food products. These bacteria are gram positive, non-spore forming and naturally present in media affluent in organic products such as food products [10].

\section{Materials \& Methods}

\subsection{Collection of Samples}

Winter vegetables (carrot, and cucumber) were collected from the retail market locations in Azimpur bazar in Dhaka city of Bangladesh. About $250 \mathrm{~g}$ each of carrot, and cucumber was obtained. The samples were wrapped separately in sterile polyethylene bags, and transported off the Industrial Microbiology Laboratory, Institute of Food Science and Technology (IFST), Bangladesh Council of Scientific and Industrial Research (BCSIR), Dhaka-1205, Bangladesh for further analysis.

\subsection{Preparation of Sample}

Sample kept at room temperature before analysis. There are many ways to carry out natural fermentation process: Ten grams each, of fresh vegetables samples 
were soaked in $90 \mathrm{ml}$ of normal saline solution ( $8.5 \mathrm{~g} \mathrm{NaCl} / \mathrm{L})$, homogenized for 20 min, appropriately diluted in normal saline. From each sample, serial dilutions were made by following the method of Harrigan (1998) [11].

\subsection{Purification of Culture Isolates}

The typical colonies on MRS agar were sub-cultured on the same medium again and again until a pure growth for each culture isolate was obtained. Four or five times subcultured in this procedure on MRS Agar media.

\subsection{Identification of Bacteria from Pure Culture}

\subsubsection{Identification of Lactobacillus spp}

The bacteriocin producers from naturally fermented carrot, and cucumber were isolated by streak plate method technique as per the traditional method [12] using MRS agar. After incubation for 48 hour at $32^{\circ} \mathrm{C}$, typical colonies were isolated and exonerated. The isolates were differentiated on the base of their morphological, cultural and physiological feature such as oxidase test, utilization of citrate as a sole carbon source and catalase test [13], and accordingly were tentatively recognize up to the genus level [14].

\subsubsection{Morphological Examination}

The colony characteristics on solid medium and cellular morphology of culture isolate after Gram's staining were examined at each step of incubation according to the methods of Collins et al. [15] for identification. The Gram's staining after slide preparation and smear fixation was performed by the following procedure:

\subsubsection{Biochemical and Enzymatic Tests}

The following biochemical tests were carried out according to the methods described by Harrigan (1998).

\section{1) Procedure of Catalase test}

At first fresh glass slide were taken. Then one drop of $3 \%$ hydrogen peroxide taken on the glass slide. After the use of loop pick up test organism and touch on the $3 \%$ hydrogen peroxide solution. Then waited 2 minutes for observation of bubble. Salmonella used positive control in this procedure.

\section{2) Procedure of Oxidase Test}

At first taken Whatman filter paper on the experimental table. Then it places one drop oxidase reagent (P-aminomethyl aniline oxalate). After the place of isolated colony by the use of loop. Waited 10 - 30 second to observe the color and Pseudomonas used positive control in this procedure.

\section{3) Procedure of Methyl red test}

This test was conducted to detect the organisms, which produced acid during the fermentation of glucose. The ingredients were dissolved in distilled water. The $\mathrm{pH}$ was adjusted to 7.5 and the medium was distributed in $5 \mathrm{~mL}$ amounts in test tubes. Then these test tubes were sterilized at $115^{\circ} \mathrm{C}$ for 20 minutes. The medium was inoculated with the specific/test organisms and incubated at $37^{\circ} \mathrm{C}$ for 48 - 72 hours using 5 drops of methyl red indicator (0.1g of methyl red in 300 
$\mathrm{mL}$ of $95 \%$ ethanol, made up to $500 \mathrm{~mL}$ in distilled water). E. coli used positive control and Pseudomonas used as a negative control. The results were recorded for acid production with change in color.

\section{4) Procedure of VP (Voges Proskauer) Test}

Isolated test organism incubated $37^{\circ} \mathrm{C}$ at $48 \mathrm{~h} .40 \% \mathrm{KOH}$ (Baritts reagent B) and $5 \%$ sodium of alpha naphthol (Baritt's reagent $A$ ) were added. After the tube was shaken vigorously and allowed to stand for 20 minutes. E. coli used negative control and Bacillus cereus used as a positive control.

\section{5) Carbohydrate fermentation test}

Phenol red broth base medium was used as a medium for this experiment. Various sugar substrates namely, sucrose, maltose, lactose, sorbitol, and glucose were used. 0.1 gram $(0.1 \% \mathrm{w} / \mathrm{v})$ of each sugar substrate was added to $100 \mathrm{ml}$ of the medium. $5 \mathrm{ml}$ of each mixture was transferred into each tube. For gas identify, Durham tube was added into the test tube containing glucose. All the tubes were sterilized for 15 minutes at $121^{\circ} \mathrm{C}$. The tubes were inoculated with a single colony of the bacteria under study. The positive reaction of the bacteria was reported by the changes in the colour of the medium [16].

\subsection{Maintenance of Pure Culture}

The pure cultures were maintained in Industrial Microbiology Laboratory of Institute of Food Science and Technology (IFST), Bangladesh Council of Scientific and Industrial Research (BCSIR), Dhanmondi, Dhaka, at refrigeration temperature with a continuous sub culturing techniques on MRS agar after every 10 days in order to avoid any contamination and other problems.

\subsection{Screening of Isolates for Antimicrobial Activity}

\section{Well Diffusion Method}

Antimicrobial activity of the bacterial isolates against all the pathogenic microbes was ascertained by well diffusion method [17] under aerobic conditions. Agar plates were inoculated with $100 \mathrm{~mL}$ of each target microbes after growing them in a broth and diluting favourably. Wells $(3 \mathrm{~mm})$ were excise into the plates and $100 \mathrm{~mL}$ of cell-free culture supernatant fluid of the different strain was placed into every well. The inhibitory activity against Escherichia coli, E. coli 12079, E. coli fecalis, Acetobacter, Bacillus cereus, Bacillus subtilis, Bacillus megaterium, Pseudomonas, Pseudomonas aeruginosa, Salmonella typhi, Salmonella typhimoreum, Staphylococcus spp., Staphylococcus aureus was grown nutrient agar. Plates were kept at a cool temperature for $2 \mathrm{~h}$ and then incubated at $37^{\circ} \mathrm{C}$ for 24 hours. The antimicrobial activity was identified by measuring the diameter of the inhibition zone around the wells.

\subsection{Purification of Bacteriocin from Lactobacillus spp}

The cells were harvested and the bacteriocin isolated from the cell free supernatant fluid as described by Green et al. (1997) [18]. Purification of bacteriocin from Lactobacillus spp. was given in the following. 
$50 \mathrm{ml}$ of de Man, Rogosa and Sharpe (MRS) broth and $2 \mathrm{ml}$ of Lactobacillus culture incubated at $37^{\circ} \mathrm{C}$ for 14 hours in anaerobic condition. Then $100 \mathrm{ml}$ MRS broth and $1 \%$ of Lactobacillus culture incubated at $37^{\circ} \mathrm{C}$ for 24 hours in anaerobic condition. Centrifuged at $6000 \mathrm{rpm}$ for 15 minutes at $4^{\circ} \mathrm{C}$. Cell free supernatant was concentrated to $100 \mathrm{ml}$ in a rotary vacuum evaporator. Ammonium sulfate was added at $4^{\circ} \mathrm{C}$ with stirring to $70 \%$ saturation. Centrifuged at $1000 \mathrm{rpm}$ for $20 \mathrm{~min}$ at $4^{\circ} \mathrm{C}$. Precipitate was collected and resuspended in $3 \mathrm{ml}$ distilled water at a centrifuge tube.

\subsection{Molecular Characterization of Bacteriocin by SDS PAGE Technique}

For the determination of protein profile of the lactic acid bacteria, strains previously identified by their phenotypic characteristics were submitted to SDS-PAGE as described by Laemmli [19].

\section{Preparation of Reagent for SDS PAGE Method}

\section{1) Prepare in the following reagent}

$30 \%$ acrylamide-bisacrylamide solution, $10 \%$ ammonium per sulfate (APS) [Aliquots of $200 \mu \mathrm{l}$ should be stored at $-20^{\circ} \mathrm{C}$ for single time use. APS decomposes slowly, therefore fresh solution should be prepared weekly.], 0.1\% BMB (Bromophenol blue solution) or tracking dye, Destaining solution, Staining solution (Coomassie blue gel stain), Sample loading buffer, Electrophoresis buffer ( $\mathrm{pH}$ 8.3), Stacking/Upper gel buffer ( $\mathrm{pH}$ 6.8), Separating/Lower gel buffer $(\mathrm{pH}$ 8.8).

\section{2) Preparation of separating gel (10\%)}

At first, clean and fresh glass plates were assembled in the gel casting chamber. A $10 \%$ separating gel was constructed by gently mixing the distilled water, lower gel buffer along with 10\% SDS, 30\% acrylamide-bisacrylamide solution, $10 \%$ SDS, $10 \%$ freshly prepared Ammonium per sulphate (APS) and TEMED according to given below. As soon as APS and TEMED were added to the mixture the freshly mixed solution was carefully poured immediately into the glass plate chamber with a sterile pasteur pipette without wasting a few seconds.

\section{3) Preparation of stacking gel (5\%)}

After the polymerization of the separating gel has been completed, a 5\% stacking gel mixture was prepared according to given below. Just like the separating gel, stacking gel mixture was also prepared by primarily mixing the distilled water, upper gel buffer along with 10\% SDS and 30\% acrylamide-bisacrylamide solution, 10\% APS and TEMED. The gel mixture was then rapidly poured above the previously constructed separating gel.

\section{4) Sample preparation}

The protein sample $(10 \mu \mathrm{L})$ was mixed with sample loading buffer at a ratio of 1:1 and was then boiled in a water bath for 3 minutes. During boiling precaution was taken so that the sample does not bump up. $5 \mu \mathrm{L}$ tracking dye $(0.1 \%$ Bromophenol blue) was then added to the boiled mixture. 


\section{5) Sample loading}

After the polymerization of stacking gel has been completed, the comb was removed from the glass chamber with a soft hand so that the well divider did not crack. The glass chamber was then fixed in the electrophoresis unit and was placed gently in the buffer reservoir. The wells were filled with the running buffer by pouring running buffer inside two glass chambers of the electrophoresis unit up to the top edge of the glasses. Running buffer was also poured into the main buffer reservoir up to $1 / 3^{\text {rd }}$ of the height of the reservoir. $20 \mu \mathrm{L}$ of sample was then added to the wells from the right side of the gel. $10 \mu \mathrm{L}$ of molecular weight standard (BIO-RAD) was used as a marker.

\section{6) Running the gel}

After the loading process was done carefully, the electrophoresis unit was connected with the power pack adjusting at $20 \mathrm{~mA}$ current keeping the voltage supply free. The power supply was kept on for $1-1.5 \mathrm{~h}$. As soon as the tracking dye reached the bottom level of the gel, the power supply was turned off.

\section{7) Staining and destaining of the gel}

After the run had been completed, the gel was released from the glass plates and immersed in a fresh staining solution (0.1\% Coomassie Brilliant blue R 250). The gel was then shaken on a shaker (Memmert, USA) for approximately $2 \mathrm{~h}$. Then the gel was taken out of the staining solution and flooded with destaining solution (10\% Acetic acid) and placed on a rotary shaker for more $2 \mathrm{~h}$. When the gel background became transparent, it was taken out of the destaining solution and immersed in distilled water.

\section{Results}

\subsection{Isolation \& Identification of Bacteria}

Bacteria isolated from fermented vegetable cucumber \& carrot was identified as Lactobacillus spp. by observing their colony morphology, physiological and as well as some biochemical characteristics. All isolates showed white and creamy colour on the MRS Agar plate (Figure 1). Colony morphology was observed creamy, little sticks and smooth round colonies.

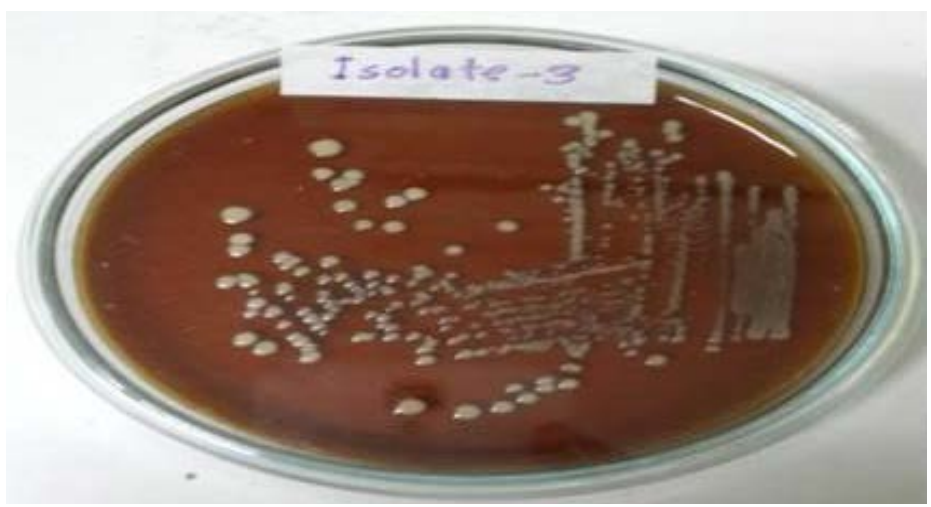

Figure 1. Lactobacillus spp. (Isolate-3) on MRS agar media. 


\subsubsection{Gram Staining}

Microscopically all isolates showed Gram-positive, rod shaped. Their morphological characteristics have shown (Table 1).

\subsubsection{Biochemical Test}

Result of Biochemical test (include: Catalase, Oxidase, Methyl Red \& Voges-Proskauer) are given below (Table 2). Carbohydrate fermentation test result is given below (Table 3). Figure 2 showed carbohydrate test of lactose.

\subsubsection{Antimicrobial Activity of Lactic Acid Bacteria Isolates against Target Bacteria by Dual Agar Overlay Method}

Antimicrobial activity of Lactobacillus spp. (isolates 1 - 6) against test organisms' result showed (Table 4). Figure 3 showed antibacterial activity of isolate-1 against Bacillus subtilis.

\subsubsection{Molecular Weight Determination of Bacteriocins}

Then SDS-PAGE electrophoresis followed by staining \& destaining, isolate 1 \& 5 showed protein band was visible by naked eye. These proteins are considered as bacteriocins. Molecular weights of the bacteriocins were determined to compare them to molecular weight marker obtained from Promega, USA. The SDS-PAGE of bacteriocins is shown (Figure 4). Bacteriocin protein band was seen when stained with Coomassie blue and it cleanly indicated the purity of protein. The molecular weight of purified bacteriocin was calculated to be about isolate 1 (40 $\mathrm{kDa})$ and isolate $5(15 \mathrm{k} \mathrm{Da}, 30 \mathrm{kDa})$.

Table 1. Morphological characterization of bacterial isolates.

\begin{tabular}{ccccc}
\hline Bacterial isolates & Source & Shape & Arrangement & Gram Staining \\
\hline Isolate - 1 & Cucumber & Long chain & Cluster & Gram positive \\
Isolate -2 & Cucumber & Small rod & Single \& Cluster & Gram positive \\
Isolate $-\mathbf{3}$ & Cucumber & Small rod & Cluster & Gram positive \\
Isolate -4 & Carrot & Long rod & Single to cluster & Gram positive \\
Isolate - 5 & Carrot & Medium chain & Cluster & Gram positive \\
Isolate - 6 & Carrot & Medium rod & Single & Gram positive \\
\hline
\end{tabular}

Table 2. Result of Biochemical test.

\begin{tabular}{ccccc}
\hline \multirow{2}{*}{ Name of Isolate } & \multicolumn{3}{c}{ Result of the Test/Appearance } \\
\cline { 2 - 4 } & Catalase & Oxidase & Methyl Red & Voges-Proskauer \\
\hline (Positive Control) & Produce bubble & Purple Color & Red color & Red color \\
Isolate-1 & Absence bubble & Colorless & Red color & Red color \\
Isolate-2 & Absence bubble & Colorless & Red color & Red color \\
Isolate-3 & Absence bubble & Colorless & Red color & Red color \\
Isolate-4 & Absence bubble & Colorless & Red color & Red color \\
Isolate-5 & Absence bubble & Colorless & Red color & Red color \\
Isolate-6 & Absence bubble & Colorless & Red color & Red color \\
(Negative control) & Absence bubble & Colorless & Yellow color & Yellow color \\
\hline
\end{tabular}


Table 3. Carbohydrate fermentation test.

\begin{tabular}{|c|c|c|c|c|}
\hline \multirow{2}{*}{$\begin{array}{l}\text { Name of } \\
\text { Isolate }\end{array}$} & \multicolumn{4}{|c|}{ Name of the Carbohydrate fermentation test: } \\
\hline & Glucose & Sucrose & Lactose & Sorbitol \\
\hline Isolate-1 & $\begin{array}{l}\text { Gas \& acid } \\
\text { Production }\end{array}$ & $\begin{array}{l}\text { No gas but acid } \\
\text { Production }\end{array}$ & $\begin{array}{c}\text { Gas but slightly acid } \\
\text { Production }\end{array}$ & $\begin{array}{c}\text { No gas but } \\
\text { acid Production }\end{array}$ \\
\hline Isolate- 2 & $\begin{array}{l}\text { Gas \& acid } \\
\text { Production }\end{array}$ & $\begin{array}{l}\text { Gas \& acid } \\
\text { production }\end{array}$ & $\begin{array}{l}\text { Gas \& acid } \\
\text { production }\end{array}$ & $\begin{array}{l}\text { Gas \& acid } \\
\text { production }\end{array}$ \\
\hline Isolate-3 & $\begin{array}{l}\text { No gas \& no acid } \\
\text { production }\end{array}$ & $\begin{array}{l}\text { Gas \& acid } \\
\text { production }\end{array}$ & $\begin{array}{l}\text { Gas \& acid } \\
\text { production }\end{array}$ & $\begin{array}{l}\text { Gas \& acid } \\
\text { production }\end{array}$ \\
\hline Isolate- 4 & $\begin{array}{l}\text { No gas but acid } \\
\text { production }\end{array}$ & $\begin{array}{l}\text { No gas but acid } \\
\text { Production }\end{array}$ & $\begin{array}{l}\text { Gas \& slightly acid } \\
\text { production }\end{array}$ & $\begin{array}{l}\text { No gas \& no acid } \\
\text { production }\end{array}$ \\
\hline Isolate-5 & $\begin{array}{l}\text { No gas but acid } \\
\text { production }\end{array}$ & $\begin{array}{l}\text { Gas \& acid } \\
\text { production }\end{array}$ & $\begin{array}{l}\text { Gas \& acid } \\
\text { production }\end{array}$ & $\begin{array}{l}\text { Gas \& acid } \\
\text { production }\end{array}$ \\
\hline Isolate- 6 & $\begin{array}{l}\text { Gas \& acid } \\
\text { Production }\end{array}$ & $\begin{array}{l}\text { Gas \& acid } \\
\text { production }\end{array}$ & $\begin{array}{l}\text { Gas \& acid } \\
\text { production }\end{array}$ & $\begin{array}{l}\text { Gas \& acid } \\
\text { production }\end{array}$ \\
\hline $\begin{array}{l}\text { Control } \\
\text { (Absent } \\
\text { Isolate) }\end{array}$ & $\begin{array}{l}\text { No gas \& no acid } \\
\text { production }\end{array}$ & $\begin{array}{l}\text { No gas \& no acid } \\
\text { production }\end{array}$ & $\begin{array}{l}\text { No gas \& no acid } \\
\text { production }\end{array}$ & $\begin{array}{l}\text { No gas \& no acid } \\
\text { production }\end{array}$ \\
\hline
\end{tabular}

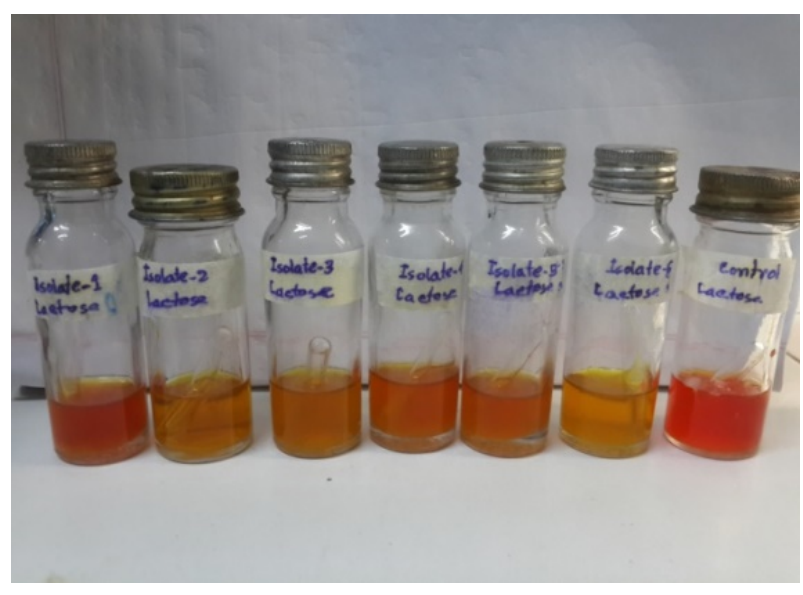

Figure 2. Carbohydrate test of Lactose.

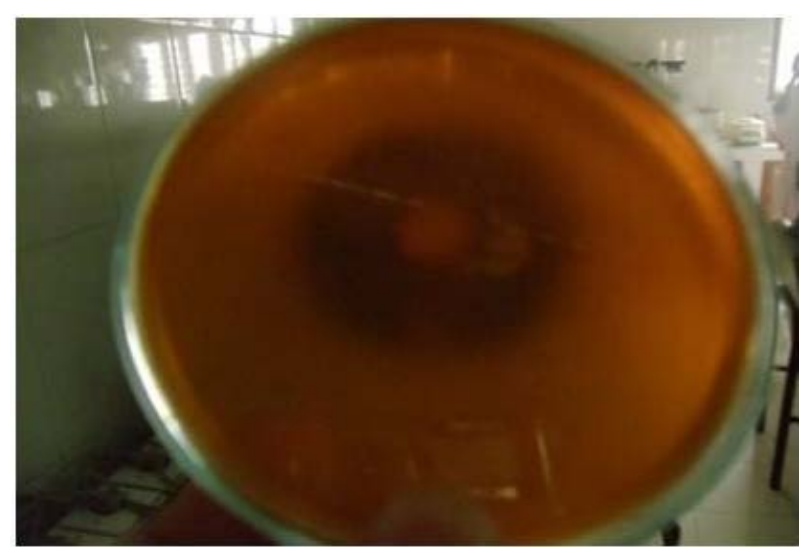

Figure 3. Antibacterial Activity of Lactobacillus spp. (Isolate-1) against Bacillus subtilis. 


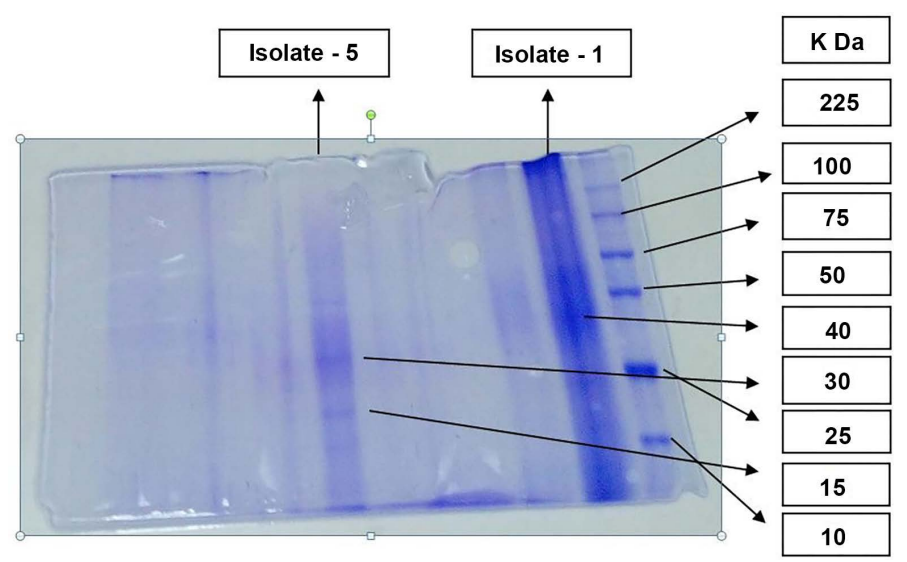

Figure 4. Molecular masses of Bacteriocin protein (40 kDa for Isolate-1, 15 $\mathrm{kDa} \& 30 \mathrm{kDa}$ for Isolate-5) obtained from SDS-PAGE method.

Table 4. Antimicrobial activity of Lactobacillus spp. (isolates $1-6$ ) against test organisms on nutrient agar media at $37^{\circ} \mathrm{C}$.

\begin{tabular}{|c|c|c|c|c|c|c|c|}
\hline \multirow{2}{*}{ Name of the Target Organism } & \multirow{2}{*}{ Media/Temperature } & \multicolumn{6}{|c|}{ Zone of diameter ( $\mathrm{mm})$} \\
\hline & & Isolate-1 & Isolate-2 & Isolate- 3 & Isolate-4 & Isolate-5 & Isolate- 6 \\
\hline Bacillus cereus & Nutrient Agar $/ 37^{\circ} \mathrm{C}$ & $35 \mathrm{~mm}$ & $20 \mathrm{~mm}$ & $47 \mathrm{~mm}$ & $40 \mathrm{~mm}$ & $35 \mathrm{~mm}$ & $35 \mathrm{~mm}$ \\
\hline Bacillus subtilis & Nutrient Agar $/ 37^{\circ} \mathrm{C}$ & $20 \mathrm{~mm}$ & $25 \mathrm{~mm}$ & $50 \mathrm{~mm}$ & $40 \mathrm{~mm}$ & $40 \mathrm{~mm}$ & $40 \mathrm{~mm}$ \\
\hline Bacillus megaterium & Nutrient Agar $/ 37^{\circ} \mathrm{C}$ & $22 \mathrm{~mm}$ & $25 \mathrm{~mm}$ & $50 \mathrm{~mm}$ & $55 \mathrm{~mm}$ & $30 \mathrm{~mm}$ & $30 \mathrm{~mm}$ \\
\hline Escherechia coli fecalis & Nutrient Agar $/ 37^{\circ} \mathrm{C}$ & $26 \mathrm{~mm}$ & $24 \mathrm{~mm}$ & $42 \mathrm{~mm}$ & $34 \mathrm{~mm}$ & $25 \mathrm{~mm}$ & $40 \mathrm{~mm}$ \\
\hline Escherechia coli 12079 & Nutrient Agar $/ 37^{\circ} \mathrm{C}$ & $45 \mathrm{~mm}$ & $40 \mathrm{~mm}$ & $43 \mathrm{~mm}$ & $50 \mathrm{~mm}$ & $35 \mathrm{~mm}$ & $35 \mathrm{~mm}$ \\
\hline Staphylococcus & Nutrient Agar $/ 37^{\circ} \mathrm{C}$ & $40 \mathrm{~mm}$ & $30 \mathrm{~mm}$ & $45 \mathrm{~mm}$ & $45 \mathrm{~mm}$ & $37 \mathrm{~mm}$ & $34 \mathrm{~mm}$ \\
\hline Staphylococcus aureus & Nutrient Agar $/ 37^{\circ} \mathrm{C}$ & $35 \mathrm{~mm}$ & $30 \mathrm{~mm}$ & $42 \mathrm{~mm}$ & $47 \mathrm{~mm}$ & $27 \mathrm{~mm}$ & $25 \mathrm{~mm}$ \\
\hline Salmonella typhimoreum & Nutrient Agar $/ 37^{\circ} \mathrm{C}$ & $30 \mathrm{~mm}$ & $25 \mathrm{~mm}$ & $40 \mathrm{~mm}$ & $42 \mathrm{~mm}$ & $24 \mathrm{~mm}$ & $25 \mathrm{~mm}$ \\
\hline Salmonella typhi & Nutrient Agar $/ 37^{\circ} \mathrm{C}$ & $30 \mathrm{~mm}$ & $45 \mathrm{~mm}$ & $40 \mathrm{~mm}$ & $45 \mathrm{~mm}$ & $35 \mathrm{~mm}$ & $30 \mathrm{~mm}$ \\
\hline Pseudomonia aeroginosa & Nutrient Agar $/ 37^{\circ} \mathrm{C}$ & $35 \mathrm{~mm}$ & $30 \mathrm{~mm}$ & $55 \mathrm{~mm}$ & $47 \mathrm{~mm}$ & $40 \mathrm{~mm}$ & $40 \mathrm{~mm}$ \\
\hline
\end{tabular}

\section{Conclusions}

The lactic acid fermentation with the bacteria has long been known and practical by the humans for making different food stuffs. Lactic acid bacteria (LAB) produce different compounds such as organic acids, diacetyl, hydrogen peroxide \& bacteriocin or bacteriocidal proteins during lactic fermentations, in this research to isolate lactic acid bacteria that have antibacterial activity of some pathogenic bacteria that are in future use as probiotic for the food industry, finally from two isolates (Isolate-1 and Isolate-5) purify and extraction of bacteriocin protein that is in future used as biopreservative in the food industry.

During purification several different protocols were applied. Optimal recovery was achieved by including ammonium sulphate precipitation. The used protocol resulted in an increase in the specific activity and $26.32 \%$ recovery. Purified bacteriocin from Lactobacillus spp. revealed homogeneity of a protein band on $10 \%$ SDS PAGE. Its molecular weight was estimated at $40 \mathrm{kDa}$ (Isolate-1) and $15 \mathrm{kDa}$, 
$30 \mathrm{kDa}$ (Isolate-5) by SDS-PAGE.

The study revealed that bacteriocin from Lactobacillus sp. isolated from natural lactic acid fermentation of vegetables (cucumber \& carrot). Lactobacillus spp. isolate possesses a wide spectrum of inhibitory activity against Escherichia coli, Staphylococcus aureus and Bacillus cereus, Bacillus subtilis, Acetobacter, E. coli fecalis, Salmonella typhi. Therefore, it has a potential for application as a biopreservative in different food products as such or in combination with other preservation methods. Additionally, this study suggests the possible role of Lactobacillus spp. in enhancing the antibacterial activity of carrot \& cucumber.

\section{Acknowledgements}

The research work was supported by Industrial Microbiology Laboratory at Institute of Food Science and Technology (IFST), under Bangladesh Council of Scientific \& Industrial Research (BCSIR), Dhanmondi, and Dhaka. Many thanks to the co-authors supported with proper assistance and help for data analysis to conduct successful research work.

\section{Conflicts of Interest}

The authors declare no potential conflicts of interest with respect to the present research work.

\section{References}

[1] Kabuki, T.H., Uenishi, M., Watanabe, H. and Nakajima, H. (2007) Characterization of a Bacteriocin, Thermophilin 1277, Produced by Streptococcus thermophulus SB1277. Letters in Applied Microbiology, 102, 971-980. https://doi.org/10.1111/j.1365-2672.2006.03159.x

[2] Stiles, M.E. (1996) Biopreservation by Lactic Acid Bacteria. Antonie Leeuwenhoek Journal, 70, 331-345. https://doi.org/10.1007/BF00395940

[3] Desmazeaud, M. and Cogan, T.M. (1996) Role of Cultures in Cheese Ripening. In: Cogan, T.M. and Joined, J.P., Eds., Dairy Starter Cultures, VCH Publishers, New York, 207-231.

[4] Cocolin, L.R., Foschino, G.C. and Fortina, M.G. (2007) Description of the Bacteriocins Produced by Two Strains of Enterococcus faecium Isolated from Italian Goat Milk. Food Microbiology, 31, 753-758. https://doi.org/10.1016/j.fm.2007.03.001

[5] Cleveland, J., Montville, T.J., Nes, I.F. and Chikindas, M.L. (2001) Bacteriocins: Safe, Natural Antimicrobials for Food Preservation. International Journal of Food Microbiology, 71, 1-20. https://doi.org/10.1016/S0168-1605(01)00560-8

[6] Toit, D.U. and Pretorius, I.S. (2002) Biopreservation of Wine with Antimicrobial Peptides. Bulletin de P O.I. V. Revue International, 75, 286-302.

[7] Ross, R.P., Morgan, S. and Hill, C. (2002) Preservation and Fermentation: Past, Present and Future. International Journal of Food Microbiology, 79, 3-16. https://doi.org/10.1016/S0168-1605(02)00174-5

[8] Daeschel, M.A. (1989) Antimicrobial Substances from Lactic Acid Bacteria for Use as Food Preservatives. Food Technology, 43, 164-167.

[9] Lilian, S.C. and Aida, R.S. (2006) Lactic Acid Production by a Strain of Lactococcus 
lactis Subs Lactis Isolated from Sugar Cane Plants. Electronic Journal Biotechnolo$g y, 9,40-44$. https://doi.org/10.2225/vol9-issue1-fulltext-10

[10] Pierre, R. (2002) Genetically Modified Lactic Acid Bacteria: Applications to Food or Health and Risk Assessment. Biochime, 84, 1073-1087. https://doi.org/10.1016/S0300-9084(02)00029-9

[11] Harrigan, W.F. and McCance, E.M. (1998) Laboratory Methods in Microbiology. Academic Press, London.

[12] Harrigan, W.F. and McCance, E.M. (1966) Laboratory Methods in Microbiology. Academic Press, London. https://doi.org/10.1016/B978-1-4832-3205-8.50005-2

[13] Fung, H.D. and Petrishoko, D.T. (1973) Capillary Tube Catalase Test. Applied Environmental Microbiology, 26, 631-632. https://doi.org/10.1128/AEM.26.4.631-632.1973

[14] Buchanan, R.E., Gibbons, N.E. and Baird-Parker, A.C. (1975) Gram-Positive Cocci. In: Bergey's Manual of Determinative Bacteriology, Williams and Wilkins Co., Baltimore, 492-515.

[15] Collins, C.H., Lyne, P.M. and Grange, J.M. (2004) Collins and Lyne’s Microbiological Methods. 8th Edition, Butterworth-Heinemann, London.

[16] Thoesen, J.C. (1994) Suggested Procedures for the Detection and Identification of Certain Finfish and Shellfish Pathogens. American Fisheries Society, 4th Edition, Version 1, Fish Health Section.

[17] Green, G., Dicks, L.M., Bruggeman, G., Vandamme, E.J. and Chikindas, M.L. (1997) Pediocin PD-1, a Bactericidical Antimicrobial Peptide from Pediococcus damnosus NCFB. Journal of Applied Microbiology, 83, 127-132. https://doi.org/10.1046/j.1365-2672.1997.00241.x

[18] Laemmli, U.K. (1970) Cleavage of Structural Proteins during the Assembly of the Head of Bacteriophage T4. Nature, 277, 680-685. https://doi.org/10.1038/227680a0

[19] Talarico, T.L. and Dobrogosz, W.J. (2005) Chemical Characterization of an Antimicrobial Substance Produced by Lactobacillus reuteri. Antimicrobial Agents and Chemotherapy, 33, 674-679. https://doi.org/10.1128/AAC.33.5.674 